search topics, employing transdisciplinary theories and methodologies. Filewod, in opening up what constitutes performance in Canadian theatre history through the case studies he examines, borrows heavily from performance studies. As a graduate student who straddles both theatre and performance studies, I was frustrated reading Filewod's framework, as it is nothing new in performance studies approaches to history. Even for Filewod this framing is not particularly original - he has been researching unconventional performances for the last two decades, such as pageants, military parades, and historical reenactments in Performing Canada: The Nation Enacted in the Imagined Theatre (2002). However, Filewod's intervention in Canadian theatre historiography in Committing Theatre proves to be an important and interesting read for both researchers of Canadian theatre and history (or historiography) more broadly. And perhaps, it is also an important read for those theatre historians performing on the CANDRAMA listerv as of late.

Megan Davies

York University

\title{
Nancy Fraser, Fortunes of Feminism: From State-Managed Capitalism to Neo-Liberal Crisis (London: Verso, 2013). 256pp. Hardback \$99.50.
}

Fraser's recent book is an impressive collection of essays published over the past 25 years detailing her interpretation of the importance of feminist politics, feminist theoretical insights on social theory, the politics of the welfare state, and neo-liberal capitalism. The chapters traverse extensive theoretical ground referencing a wide range of social theorists ranging from Karl Marx, Max Weber, and Karl Polanyi, to Michel Foucault, Raymond Williams, and Judith Butler. As Fraser argues in chapter one, a compelling "critical social theory frames its research program and its conceptual framework with an eye to the aims and activities of those oppositional social movements with which it has a partisan_though not uncritical_-identification" (19). With this objective in mind, she considers how the politics of the feminist movement can inform social theory, specifically addressing the question of how gender is, or could be, incorporated to explain male domination and female subordination in contemporary society. Her overriding goal, then, is to undertake a feminist critique of social theory but also to develop feminist models of justice responding to (welfare) state-organized capitalism and to the current neo-liberal capitalist crisis. Throughout her analyses she searches for gender blind spots or the hidden gender subtext that may inform or limit theory, while also striving to reveal the emancipatory potential of theoretical frameworks by proposing feminist models for social change. As she explains, "the goal throughout is to develop new conceptual and practical strategies for combating gender injustices of economy and culture simultaneously" (12). Following this broad approach, the chapters in Fortunes of Feminism "document major shifts in the feminist imaginary since the 1970s" (2). The 
feminist theoretical debates spanning the early second-wave to the present are depicted as a "drama in three acts" (1). Correspondingly she divides the book into three parts, charts the key political demands by feminists in each act, and explains how these changed over time.

The first act (Part I) explores the early second-wave characterized as the most transformative era. Struggles around 'the personal is political' sought to transform unequal capitalist social relations by exposing and contesting androcentricism within the economy, polity and culture that are fundamental to male power. Feminist challenges to seemingly gender-neutral categories such as 'work' and 'worker' redefined politics by questioning established views of class inequality that overlooked matters of gender injustice. Interestingly, Fraser undertakes a feminist critique of Habermas arguing that he advances a theory of social reproduction but is unaware of how his theory has deep gender implications. For instance, Habermas does not acknowledge that the male-headed nuclear family is "thoroughly permeated by money and power" (29) or that the relationship between the public and private spheres has gender connotations. Discursive feminist struggles had implications for welfare state measures but were also important for "a critical social theory of capitalist societies that need gender-sensitive categories" (38). Fraser argues the first act in the drama was the most visionary in expanding "the boundaries of contestation beyond socio- economic distribution to include housework, sexuality and reproduction" (3).

In act two (Part II) Fraser observes a shift in the feminist political imaginary toward the politics of "difference". Moving away from an anti-capitalist critique and the demand for redistribution, the feminist movement veered toward a focus on cultural politics rooted in claims for recognition (9). Here Fraser critiques discourse analyses represented in neo-Lacanian structuralist theory arguing the "combination of psychologism and symbolicism in Lacanianism results in a conception of discourse that is of limited usefulness for feminist theorising" (147). Given the problems of the 'cultural turn' in feminist theory that focuses too narrowly on identity and representation, Fraser proposes a model of justice predicated on participatory parity (equal/peer participation) that combines recognition (identity) and distribution. In this model status (identity) connects to the economic (material) given that "feminist struggles for redistribution cannot succeed unless they are joined with struggles for cultural change..." (e.g. valourizing caregiving) (171). She concludes that a model of justice is necessarily integrative uniting recognition and redistribution: "In short, no redistribution without recognition" (171).

Act three (Part III) analyses feminist challenges in the present neoliberal capitalist crisis. Fraser revises her model of justice in light of changing developments within neoliberal globalization. Recognizing that the global order has shifted from what she calls a 'Keynesian-Westphalian frame' to a 'post-Westphalian' one that is less bounded by territorial states, she includes a third-dimension in her justice model — the political. In order to determine "who" are the relevant subjects, "which" is 
the relevant community, and "what" is just in a democratic society (participatory parity) the model must become "three-dimensional incorporating the political dimension of representation, alongside the economic dimension of distribution and the cultural dimension of recognition" (193). This amended model can "grasp the problem of the frame as a matter of justice" (208). However, while this three-dimensional model assumes an interrelation or interweaving of the three strands, feminists she suggests have disconnected the economic, cultural and political. Fraser states, "the three dimensions of gender injustice became separated, both from one another and from the critique of capitalism" (211) and as a consequence feminism has" entered a dangerous liaison with neoliberalism" (14). Rather than engaging in a movement for radical change grounded on solidary relations and the "promise of emancipation" as was the goal in act one, feminists have inadvertently played into the hands of neoliberalism. For instance, the second-wave critique of the familywage was "resignified" in neoliberalism expanding dual-earner households and exacerbating the double day. Moreover, the second-wave critique of (welfare) state managed capitalism has given way to support for NGOs micro-credit programs that serve to individualize and marketize anti-poverty policy. Fraser argues act three is still in play and, therefore, it is imperative for feminists not only to be alert to the ambivalences and contradictions arising from feminist struggle, but also to retrieve from act one the "structural critique of capitalism's androcentricism, its systematic analysis of male domination, and its gender-sensitive revisions on democracy and justice" (1).

Fraser concludes that the current neoliberal crisis is reviving interest in the feminist critique of political economy whereas the politics of recognition is losing credibility. Overall developments in global capitalism, she suggests, such as the near collapse of finance capital, the decline of democracy in Western societies, and the attack on social reproduction, demand a response from feminists — and feminist theorizing that combines the insights from previous decades of feminist activism. While I agree there is a need to recover feminist insights from previous decades of activism, that reviving the "emancipatory promise of feminism" can rekindle feminist struggle, that a return to more grand theorizing or a holistic vision is necessary in this period of neoliberal crisis, I am less persuaded that recognition politics has lost its currency, especially in view of the politics of mass migration, the upsurge of Black Lives Matter, and the ongoing struggles by LGBTQ and Aboriginal peoples. Some of these struggles have been informed by feminist activism and, in my estimation, do not run aground in balancing redistribution, recognition and representation nor do they unconsciously or ambiguously lend support to liberal individualism, legitimize marketization, and encourage state retrenchment. For instance, struggles by female migrant domestics for expanded citizenship are based on state intervention, and achieving autonomy from market-based processes that govern their employment and immigration status, while the demands of Black Lives Matter are not restricted to policing but to issues of their broader marginalization that pre- 
vents them from participating in the economic, political and cultural spheres of life.

Fraser's book is a sophisticated analysis of feminist political theory that demands a lot from its readers-but coming to terms with her arguments is well worth the effort.

Jan Kainer

York University

\section{Angela Brintlinger and Ilya Vinitsky, eds., Madness and the Mad in Russian Culture (Toronto; Buffalo: University of Toronto Press, 2015). 344pp. Paper- back $\$ 37.95$.}

From melancholy under Catherine the Great to the fan hysteria surrounding Vsevolod Garshin to Russian evaluations of shell shock during World War I, this collection of fifteen essays covers a vast territory. Rather than providing readers with a comprehensive history of madness, the volume offers important individual studies with each author looking at the problem from a unique angle. Hence even the madness in the title changes - the subject can be melancholy, insanity, craziness and the mental reasons behind suicide. The essays are organized in a more or less chronological order and expose the reader to the phases of mental health in Russia and the Soviet Union.

The historically-inclined essays balance the weaknesses of an empire slow to industrialize with the critical contributions Russians made to modern science. Lia Iangoulova argues that even if being sent to a zemstva (rural self-administration) asylum was a virtual death sentence, the Kazan Regional asylum was "a psychiatrist's dream" (47). Over the course of the nineteenth century, Russian law came to recognize "psychiatric examination" in a scientific manner (53). Irina Sirotkina argues that Russian psychiatrists were more willing to advocate "mild treatment of war neurotics" in World War I because of their antipathy to the war and the tsarist government. Interestingly, this sympathy can be also be ascribed to the absence of a pension system in Russia so the state did not have to worry about added financial burdens (124).

Most of the essays, however, are anchored in the tradition of literary analysis and focus on the relationship of madness to the work and lives of important authors: Catherine the Great, Pushkin, Dostoevsky, Garshin, and Chekhov have individual works examined. In keeping with literary criticism, these essays analyze the intersection of lived experience with the content of fictional works. Vsevolod Garshin, a late nineteenth-century writer who suffered from mental illness, had a cult following amongst hysteric fans. According to Robert D. Wessling, "popularized theories of mental illness combined with the literary aesthetics of the 1880 s... to generate codes of behaviour for his associates and fans" (76). In other words, the personality and the writings of Garshin had a "paralysing effect" on his fans (82). 